\title{
Non-Enzymatic Glycosylation of Serum Proteins as an Indicator of Diabetic Control
}

Dear Sir,

It has been demonstrated that haemoglobin $\mathrm{A}_{1}\left(\mathrm{HbA}_{1}\right)$ and glycosyl-albumin are valuable tools in monitoring diabetic control [1, 2]. Recently an increased non-enzymatic glycosylation of serum proteins (GSP) has been observed in diabetic subjects [3]. Therefore we have examined whether GSP is related to the degree of diabetic control, as assessed by $\mathrm{HbA}_{1}$, fasting blood glucose and urinary glucose excretion.

We have investigated blood glucose levels, $\mathrm{HbA}_{1}$ and GSP in 17 control subjects (age 28-72 years, mean 52 years) and 44 diabetic patients (age 25-75 years, mean 48 years) following an overnight fast. In addition, the degree of medium-term diabetic control was evaluated on the basis of at least three fasting blood glucose values and $24 \mathrm{~h}$ urinary glucose excretion performed at regular intervals during the 2-week period before the GSP and $\mathrm{HbA}_{1}$ assays. Patients were divided into three groups according to their metabolic control: good, no $24 \mathrm{~h}$ glycosuria and fasting glycaemia $<7.2 \mathrm{mmol} / 1$; fair, $24 \mathrm{~h}$ glycosuria $<555 \mathrm{mmol}$ and glycaemia $<8.3 \mathrm{mmol} / 1$; poor, $24 \mathrm{~h}$ glycosuria $>555 \mathrm{mmol}$ and glycaemia $>8.3 \mathrm{mmol} / 1$. Glycosylated serum protein was measured using a modification of the method described by Kennedy et al. [3]. $\mathrm{HbA}_{1}$ was assayed by the micro-column technique (Bio-Rad, Richmond, USA).

Fasting blood glucose, $\mathrm{HbA}_{\mid}$and GSP were found to be significantly higher in the diabetic than in the control subjects (Table 1). The degree of medium-term metabolic control was assessed as good in 15 cases, fair in 16 and poor in 13. All patients but one showed GSP values which were greater than two standard deviations above the mean found in the control subjects. In the healthy subjects, GSP levels correlated with the fasting blood glucose levels $(r=0.49, p<0.05)$ and with $\mathrm{HbA}_{1}(r=0.57, p<0.05)$. In the diabetic subjects, GSP values were not correlated with fasting glycaemia $(r=0.13, p>0.05)$, but a significant correlation was found with $\mathrm{HbA}_{1}(r=0.56, p<0.001)$ and with the degree of mediumterm diabetic control evaluated by glycaemia and glycosuria levels observed during the previous 2 weeks $(r=0.69, p<0.001)$.

These results suggest that GSP is not related to short-term fluctuations in blood glucose. Glycosylated serum protein values were better correlated with the degree of diabetic control during the 15 days before the study than with $\mathrm{HbA}_{1}$. It is likely that the GSP level depends on the blood glucose level found during the half-life of the serum proteins, which ranges from 2.5 to 23 days for different fractions. The finding that GSP may be high, even in patients judged to
Table 1. Blood glucose, non-enzymatic glycosylation of serum proteins (GSP) expressed as 5-hydroxymethylfurfural (HMF) and glycosylated haemoglobin $\left(\mathrm{HbA}_{1}\right)$ in control and diabetic subjects

\begin{tabular}{llc}
\hline & $\begin{array}{l}\text { Control subjects } \\
(n=17)\end{array}$ & $\begin{array}{l}\text { Diabetic subjects } \\
(n=44)\end{array}$ \\
\hline $\begin{array}{l}\text { Fasting blood } \\
\text { glucose }(\mathrm{mmol} / 1)\end{array}$ & $4.47 \pm 0.39$ & $8.82 \pm 3.33^{\mathrm{a}}$ \\
$\begin{array}{l}\text { GSP(HMF nmol/mg } \\
\text { protein) }\end{array}$ & $0.51 \pm 0.09$ & $0.97 \pm 0.17^{\mathrm{a}}$ \\
$\mathrm{HbA}_{1}(\%)$ & $5.96 \pm 0.56$ & $10.41 \pm 2.02^{\mathrm{a}}$ \\
\hline
\end{tabular}

Results expressed as mean $\pm \mathrm{SD}$

${ }^{a}$ Difference from controls: $p<0.001$

have good or fair metabolic control, could indicate that serum proteins may undergo significant glycosylation in response to blood glucose concentrations which are not particularly high. Alternatively, it could confirm the unreliability of assessing diabetic control by the usual criteria.

In conclusion we believe that GSP is a useful index of carbohydrate intolerance and provides a method for evaluating mediumterm metabolic control, thus providing a valid means of monitoring the efficacy of therapy.

Yours sincerely,

G. Gragnoli, I. Tanganelli, A. M. Signorini, P.Tarli and C.Paoli

\section{References}

1. Bunn FH, Gabbay KH, Gallop PM (1978) The glycosylation of hemoglobin: relevance to diabetes mellitus. Science 200: 21-27

2. Dolhofer R, Wieland OH (1980) Increased glycosylation of serum albumin in diabetes mellitus. Diabetes 29:417-422

3. Kennedy AL, Mehl TD, Merimee TJ (1980) Non-enzymatically glycosylated serum proteins: spurious elevation due to free glucose in serum. Diabetes 29:413-415

G. Gragnoli

Clinica Medica Università di Siena

Siena, Italy

\section{Erratum}

Diabetologia, Volume 22, No. 1 (January)/1982

Apart from the first paper by Tomlinson et al. and the Organization Section at the end of the issue, all papers begin one page earlier than the page numbers given on the cover.

We wish to apologise for this error which will not affect page references in the Contents and the Subject and Author Indexes of Volume 22.

\section{Announcement}

Satellite Symposium "Immunology and Diabetes". A Satellite Symposium on "Immunology and Diabetes" will be held in Luxembourg from 14-15 April 1982. This Symposium will precede the 16th Annual Meeting of the European Society for Clinical Investigation (Luxembourg: 15-17 April 1982). For further information please contact: Drs. F. A. Gries and H. Kolb, Diabetes Forschungsinstitut, Universität Düsseldorf, Auf'm Hennekamp 65, D-4000 Düsseldorf, FRG or Dr. G. Schernthaner, II. Medizinische Universitätsklinik, Universität Wien, Garnisongasse 13, A-1090 Wien, Austria.

Responsible for the text: Dr. A. G. Cudworth, Department of Diabetes, Medical Unit, King George V Building (5th Floor), St. Bartholomew's Hospital, London EC1A 7BE, England

Responsible for advertisements: E. Lückermann, B. Schultz, Kurfürstendamm 237, D-1000 Berlin 15. Springer-Verlag Berlin Heidelberg New York

Printed in Germany by aprinta, Wemding

Copyright (c) Springer-Verlag GmbH \& Co. KG, Berlin Heidelberg 1982

Diese Ausgabe enthält eine eingeheftete Beilage vom Springer Verlag, Berlin, Heidelberg, New York. 